\title{
Irisin and the therapeutic benefits of exercise
}

\author{
Bruce M Spiegelman*, Stanley J Korsmeyer \\ From Metabolism, diet and disease \\ Washington, DC, USA. 29-31 May 2012
}

We are experiencing a worldwide epidemic of obesity and type II diabetes. Our group has been interested in the development of both white and brown fat, particularly at the level of gene transcription. PGC1 $\alpha$ was first described as a coactivator of PPAR $\gamma$ in the control of brown fatmediated thermogenesis. More recent work has shown that PGC1 $\alpha$ controls much of an exercise program in skeletal muscle. We have now found that PGC1 $\alpha$ expression and exercise control the expression of Fndc5, a membrane protein of skeletal muscle. Fndc 5 is proteolysed to give rise to a new secreted protein of 112 amino acids that we have called irisin. Irisin circulates in both muse and man, and even mild elevations of irisin activates the browning of white fat, causing increased energy expenditure and reducing obesity. Irisin administration via adenoviral vectors also greatly improves glucose homeostasis in high-fat fed mice. Most recently we have identified cell surface binding of irisin that is likely to represent a cell surface receptor. These data indicate that irisin is a protein regulated in muscle by exercise that gives some of the benefits of exercise on energy homeostasis and metabolic disease.

Submit your next manuscript to BioMed Central and take full advantage of:

- Convenient online submission

- Thorough peer review

- No space constraints or color figure charges

- Immediate publication on acceptance

- Inclusion in PubMed, CAS, Scopus and Google Scholar

- Research which is freely available for redistribution

\section{() Biomed Central}

